\title{
PUBLIC, PRIVATE AND FOREIGN INVESTMENT NEXUS IN THE REPUBLIC OF NORTH MACEDONIA: CROWDING-IN OR OUT EFFECT?
}

\author{
Vesna Garvanlieva Andonova \\ Faculty of Economics - Skopje, Ss. Cyril and Methodius University in Skopje \\ Center for Economic Analyses, CEA \\ vesna_nl@yahoo.com
}

\begin{abstract}
In the last two decades the economic growth of North Macedonia can be qualified as sluggish and volatile. In this period, the government has been proclaiming a narrative of fiscal and economic policies focused on public investment driven development and growth, yet the capital budget bias, has been significant with regularly overestimated plans vs. the outturn. The public investment-to-GDP ratio, has been an average 5.47\%, ranging from minimum 4.0\% (Y2007) to maximum $6.7 \%$ (Y2010). Simultaneously, the private investment-to-GDP ratio has been an average $17.1 \%$, with minimum of $15 \%$ (in Y2005) and a maximum value of $20.6 \%$ (in Y2008). The FDI inflows, have been ranging from minimal below 1\% in 2014 to maximum $12.7 \%$ in 2001 , with average of $4.6 \%$ per annum. The trends of the variables straightforwardly do not suggest a nexus between public and private investments i.e. causing crowding-in or crowding out effect. In this paper it is investigated whether public investment and foreign direct investments crowd-out or crowd-in the private investment in North Macedonia. To test this hypothesis, we use the available annual data on private investment, public investment, foreign direct investments and GDP for the period of 2000-2017 (in real terms). A model of autoregressive distributed lag bound testing is used for the variables private investment, public investment, GDP and foreign direct investment. The results indicate a crowding-out effect of public over private investments with significance of the foreign direct investments are expected to show whether there is crowding-in or -out effect of the public over private investment and crowding-in effect of the foreign direct investments. The crowding-out effect is immediate and short run.
\end{abstract}

Keywords: private investment, public investment, crowding-out effect, ARDL bound testing

JEL classification: E22, H54, H11

http://hdl.handle.net/20.500.12188/15932

http://doi.org/10.47063/EBTSF.2021.0019 